\title{
PEMANFAATAN SERAT PELEPAH KELAPA SAWIT SEBAGAI BAHAN PEMBUATAN KAMPAS REM SEPEDA MOTOR
}

\section{UTILIZATION MIDRIB FIBERS OF OIL PALM AS A MATERIAL FOR MOTORCYCLE BRAKE PADS}

\author{
Guntoro $^{1}$, Ingrid Ovie Yosephine ${ }^{1 凶}$, Simon Simanjuntak ${ }^{\mathbf{1}}$ \\ ${ }^{1}$ Budidaya Perkebunan, Sekolah Tinggi Ilmu Pertanian Agrobisnis Perkebunan \\ ${ }^{\otimes}$ Komunikasi Penulis, email: ingrid_ovie@stipap.ac.id \\ DOI:http://dx.doi.org/10.23960/jtep-lv10i2.155-160 \\ Naskah ini diterima pada 26 Maret 2021; revisi pada 7 April 2021; \\ disetujui untuk dipublikasikan pada 12 April 2021
}

\begin{abstract}
Brake pads are generally made of asbestos, which is less environmentally friendly and widely available in nature, therefore motorcycle brake pads are made that utilize palm frond fibers filled with alumina powder and bonded to a polyurethane matrix. This research was conducted at the Laboratory of Material Testing of Industrial Chemical Technology Polytechnic (PTKI) Medan. Research was carried out from February-July 2020, using two test, namely the Rockwell Hardness level test and the Pin On Disk Friction Coefficient test. The result showed that oil palm frond fibers can be made into motorcycle brake pads with the addition of alumina powder according to the predetermined composition. After going through the test, the Rockwell hardness level was obtained in A2 treatment (6\% Alumina) with the highest and best hardness level, namely $52.75 \mathrm{Kg}$. And after testing the friction coefficient of the Pin On Disk type, brake pads from palm frounds with the addition of alumina powder composition which have the lowest coefficient value of the best are obtained in treatment A2 (6\% Alumina) with a value of $0.000765 \mathrm{~N} / \mathrm{mm}^{2}$.
\end{abstract}

Keywords : biocomposite, brake shoes, palm fround fibers, alumina powder

\begin{abstract}
ABSTRAK
Kampas rem pada umumnya dibuat dari bahan asbestos yang kurang ramah lingkungan. Teknologi biokomposit berpenguat serat alam dikenal lebih ramah lingkungan dan ketersediaannya banyak di alam, oleh karena itu dibuat kampas rem sepeda motor yang memanfaatkan serat pelepah kelapa sawit dengan pengisi serbuk alumina dan di rekat matrik poliuretan. Penelitian ini dilaksanakan di Laboratorium Uji Material Politeknik Teknologi Kimia Industri (PTKI) Medan. Waktu Penelitian dilaksanakan dari bulan Februari-Juli 2020, dengan menggunakan dua pengujian, yaitu pengujian tingkat Kekerasan Rockwell dan pengujian Koefisien Gesek Pin On Disk. Hasil penelitian menunjukkan bahwa serat pelepah kelapa sawit dapat dibuat menjadi kampas rem sepeda motor dengan penambahan serbuk alumina sesuai komposisi yang telah ditentukan. Setelah melalui uji coba tingkat kekerasan Rockwell didapat pada perlakuan A2 (6\% Alumina) dengan tingkat kekerasan paling tinggi dan paling baik, yaitu 52,75 Kg. Dan setelah melalui uji coba koefisien gesek jenis Pin On Disk, kampas rem dari pelepah kelapa sawit dengan komposisi penambahan serbuk alumina yang memiliki nilai koefisien terendah atau yang paling baik didapat pada perlakuan A2 (6\% Alumina) dengan nilai $0.000765 \mathrm{~N} / \mathrm{mm}^{2}$.
\end{abstract}

Kata Kunci: biokomposit, kampas rem, serat pelepah kelapa sawit, serbuk alumina

\section{PENDAHULUAN}

Tanaman kelapa sawit (Elaeis guineensis Jacq) merupakan tanaman utama dalam industri perkebunan kelapa sawit di Indonesia. Tercatat pada tahun 2018, luas areal perkebunan kelapa sawit di Indonesia mencapai 14.326 .350 ha dengan produksi CPO sebesar 42.883.631 Ton (Direktorat Jendral Perkebunan, 2019). Perkebunan kelapa sawit memproduksi tandan buah segar (TBS) yang akan dijadikan sebagai produk utamanya yaitu minyak goreng, disamping itu dalam proses untuk mendapatkan TBS tersebut perkebunan kelapa sawit 
menyisakan pelepah kelapa sawit yang menjadi salah satu limbah padat dalam perkebunan kelapa sawit.

Pelepah kelapa sawit dihasilkan setelah melakukan kegiatan penunasan dan kegiatan pemanenan tanaman kelapa sawit yang menjadi salah satu limbah tanaman kelapa sawit. Menurut Elgani (2013) pohon kelapa sawit memiliki jumlah pelepah optimum 40-56 pelepah pada usia muda dan 40-48 pelepah pada masa usia tua, penunasan bertujuan supaya hasil produksi maksimum dan memperkecil kehilangan produksi. Limbah pelepah sawit pada luasan areal $1 \mathrm{Ha}$ dapat menghasilkan 10 ton/ha/ Tahun (Subhan, et al., dalam Dabuke, 2018), apabila dengan jumlah pelepah yang besar ini tidak dilakukan pengolahan khusus, maka akan menjadi masalah. Padahal Pelepah daun sawit ini sangat berpotensi digunakan sebagai bahan kampas.

Salah satu komponen penting yang terdapat dalam setiap kendaraan yang berfungsi memperlambat dan menghentikan laju kendaraaan adalah sebuah kampas rem. Kampas rem di pasaran umumnya dibuat dari bahan serat asbestos yang tidak ramah lingkungan dan membahayakan kesehatan manusia, terutama pada pernapasan dan dapat menyebabkan kanker paru-paru (Fitrianto, et al., 2013). Banyak penelitian yang memanfaatkan serat alam sebagai pengganti serat asbestos yang disebut dengan biokomposit (Gibson, 1994)

Kecenderungan teknologi biokomposit polimer berpenguat serat khususnya serat alam saat ini mulai diminati alasannya ramah lingkungan, ketersediaan di alam banyak, dan biaya produksi yang rendah (Mallick, dalam Aminur, et al., 2015). Oleh karena itu, dibuat bahan kampas rem dari non asbestos dengan teknologi biokomposit yang memanfaatkan serat pelepah kelapa sawit dan pengisi serbuk alumina yang direkat matrik poliuretan.

\section{BAHAN DAN METODE}

Penelitian ini dilaksanakan di Laboratorium Uji Material Politeknik Teknologi Kimia Industri (PTKI) Medan. Penelitian dilakukan pada bulan
Februari-Juli 2020. Penelitian ini dilakukan dengan menggunakan metode eksperimental desain Rancangan Acak Lengkap (RAL) non faktorial dengan satu faktor yang diteliti, yaitu dengan variasi konsentrasi alumina (A) sebagai berikut:

$$
\begin{aligned}
\text { A0 } & =\text { Konsentrasi Alumina sebesar 0\% (tanpa } \\
& \text { alumina) } \\
\text { A1 } & =\text { Konsentrasi Alumina sebesar 3\% } \\
\text { A2 } & =\text { Konsentrasi Alumina sebesar } 6 \% \\
\text { A3 } & =\text { Konsentrasi Alumina sebesar } 9 \%
\end{aligned}
$$

Alat yang digunakan dalam proses pembuatan serat pelepah berupa parang/pisau besar, palu serta bahan utama yaitu pelepah kelapa sawit yang diambil dari perkebunan kelapa sawit sedangkan alat untuk membuat kampas rem berupa kompaksi hidrolik, wadah untuk pengaduk nahan perekat, timbangan digital, kertas pasir, lempengan dudukan kampas rem (jenis tromol), alat uji kekerasan Rockwell dan koefisien gesek jenis pin on disk. Sedangkan bahan serat dari pelepah kelapa sawit, matrik jenis poliurethane dan serbuk alumina.

\subsection{Tahapan Penelitian}

Alat dan bahan yang telah disiapkan kemudian dilakukan proses pembuatan kampas rem. Kampas rem dengan pengisi serbuk alumina terlebih dahulu melakukan formulasi campuran dengan penambahan berat alumina 0, 3, 6,dan 9 $\%$, dan matrik Poliuretan dalam fraksi total volume serat. Dari masing-masing campuran itu dibuatlah kampas rem jenis tromol dengan penekanan kompaksi hidrolik. Kemudian specimen dari setiap perlakuan dilakukan pengujian kekerasan dan koefisien gesek. Data yang diperoleh dari setiap pengujian dihitung nilai rata-rata dan disajikan dalam bentuk tabel dan juga grafik untuk mempermudah analisa dan pembahasan.

\subsection{Pengamatan dan Indikator}

Sifat mekanik material, merupakan salah satu faktor terpenting yang mendasari pemilihan bahan dalam suatu perancangan. Sifat mekanik dapat diartikan sebagai respon atau perilaku material terhadap pembebanan yang diberikan, dapat berupa gaya, torsi atau gabungan keduanya. Sifat kekerasan sangat diperlukaan oleh setiap bahan yang dibuat. 
1) Sifat Kekerasan

Kekerasan yaitu kemampuan material menahan deformasi plastis lokal akibat penetrasi pada permukaan. Kekerasan suatu bahan biokomposit erat kaitannya atau sangat tergantung dengan sifat-sifat kedua penyusunnya yaitu penguat (reinforcement) dan perekat (matrix).

Dalam penelitian ini peneliti menguji kekerasan kampas rem dengan menggunakan metode Rockwell, pengujian kekerasan dengan metode Rockwell bertujuan menentukan kekerasan suatu material dalam bentuk daya tahan material terhadap benda uji (speciment) yang berupa bola baja ataupun kerucut intan yang ditekankan pada permukaan material uji tersebut.

\section{2) Koefisien Gesek}

Suatu komponen struktur dan mesin agar berfungsi dengan baik sebagaimana mestinya sangat tergantung pada sifat-sifat yang dimiliki material. Sifat yang dimiliki oleh material terkadang membatasi kinerjanya. Namun demikian, jarang sekali kinerja suatu material hanya ditentukan oleh satu sifat, tetapi lebih kepada kombinasidari beberapa sifat. Salah satu contohnya adalah koefisien gesek.

Dalam penelitian ini peneliti menguji koefisien gesek kampas rem menggunakan alat uji bernama Pin On Disk, dimana benda uji atau bisa disebut disk diputar dengan kecepatan $230 \mathrm{rpm}$ yang mendapat kontak gesek dari pin diatas nya yang diberikan beban tekanan 9,80 $\mathrm{N}$ pada pin. Pembebanan gesek ini akan membuat pin menekan disk dan menghasilkan kontak antar permukaan yang berulang-ulang yang pada akhirnya akan mengikis sebagian benda uji atau disk pada permukaan benda uji atau disk. Besarnya jejak permukaan pada disk yang tergesek itu dijadikan dasar penentuan koefisien gesek pada benda uji. Semakin kecil nilai koefisien gesek suatu material, semakin baik kualitas material tersebut.

\section{HASIL DAN PEMBAHASAN}

\subsection{Komposisi Campuran Bahan Pembuatan Kampas Rem}

Dalam pembuatan kampas rem berbahan dasar serat alam/biokomposit dibutuhkan bahan pendukung lainnya selain serat alam itu sendiri dengan fungsinya masing-masing dan untuk mencapai hasil yang maksimal maka dilakukan komposisi antar ketiga bahan. Komposisi bahan pembuatan kampas rem terdapat pada Tabel 1.

Dari Tabel 1 diketahui jika komposisi ketiga jenis bahan tersebut disatukan maka akan didapat totalnya 25 gr dengan rinciannya yaitu, poliuretan A 10 gr dan poliuretan B 5 gr yang jumlahnya tetap di setiap perlakuan, kemudian berat serat pelepah kelapa sawit yang mula-mula adalah $10 \mathrm{gr}$ dan selanjutnya berkurang di setiap perlakuan karena penambahan sebuk alumina sebagai wujud perlakuannya yang beratnya di dapat dari perhitungan total dari keseluruhan berat bahan.

\subsection{Uji Kekerasan Rockwell}

Pengujian kekerasan dengan metode Rockwell bertujuan menentukan kekerasan suatu material dalam bentuk daya tahan material terhadap benda uji (speciment) yang berupa bola baja ataupun kerucut intan yang ditekankan pada permukaan material uji tersebut. Hasil uji kekerasan pada kampas rem berbahan dasar serat pelepah kelapa sawit dapat dilihat pada Tabel 2.

Hubungan komposisi serbuk alumina terhadap kekerasan material biokomposit kampas rem menunjukkan bahwa tiap perlakuan tidak

Tabel 1. Komposisi Bahan Pembuatan Kampas Rem

\begin{tabular}{cccccc}
\hline No & $\begin{array}{c}\text { Perlakuan } \\
\text { (\%) }\end{array}$ & $\begin{array}{c}\text { Berat } \\
\text { Pelepah (gr) }\end{array}$ & $\begin{array}{c}\text { Berat Alumina } \\
\text { (gr) }\end{array}$ & $\begin{array}{c}\text { Poliuretan A } \\
\text { (gr) }\end{array}$ & $\begin{array}{c}\text { Poliuretan B } \\
\text { (gr) }\end{array}$ \\
\hline 1 & A0 (0) & 10 & 0 & 10 & 5 \\
2 & A1 (3) & 9.25 & 0.75 & 10 & 5 \\
3 & A2 (6) & 8.5 & 1.5 & 10 & 5 \\
4 & A3 (9) & 7.75 & 2.25 & 10 & 5 \\
\hline
\end{tabular}


berbeda nyata dan atau tidak memberikan pengaruh yang signifikan terhadap kekerasan kampas rem. Hal ini juga sesuai dengan Standarisasi Internasional (SAE J661,1997), bahwa pada Tabel 2 diperoleh nilai kekuatan tertinggi pada perlakuan A2 (6\% alumina) hanya mencapai sebesar $52,75 \mathrm{~kg}$. Berdasarkan Standarisasi Internasional (SAE J661,1997) nilai keamanan dan standar kekerasan kampas rem untuk sepeda motor adalah $68-105 \mathrm{~kg}$, dengan kata lain kekuatan kampas rem masih di bawah standar kekuatan SAE J661 (1997). Untuk lebih jelas dapat dibuat Gambar 1.

Dari Gambar 1 dapat dilihat bahwa nilai kekerasan tertinggi terdapat pada perlakuan A2 (6\% alumina) dengan nilai kekerasan sebesar $52,75 \mathrm{~kg}$ sedangkan nilai kekerasan terendah terdapat pada perlakuan A1 (3\% alumina) dengan nilai kekerasan sebesar 43,5 kg. Biokomposit pada perlakuan A2 adalah yang terbaik, karena pada uji tingkat kekerasan kampas rem metode Rockwell material yang dapat menahan daya tekanan yang paling tinggi sehingga merupakan material yang paling baik.

\subsection{Uji Koefisien Gesek Pin On Disk}

Dalam pengujian koefisien gesek pin on disk dibuat sampel berbentuk piringan dari setiap perlakuan kemudian sampel diletakkan pada alat uji yang akan di operasikan alat pin on disk dengan kecepatan putar 230 rpm selama 60 detik, lalu pin diatas alat uji diberikan beban tekanan sebesar 9,80 $\mathrm{N}$ yang akan mengikis benda uji. Lalu sampel ditimbang kembali dan setiap nilai yang didapat dimasukan dalam perhitungan koefisien gesek. Dari perhitungan tersebut diperoleh nilai rata-rata koefisien gesek kemudian disajikan dalam bentuk tabel dan grafik.

Hubungan komposisi serbuk alumina terhadap keofisien gesek material biokomposit kampas rem menunjukkan bahwa tiap perlakukuan berbeda sangat nyata dan atau memberikan pengaruh yang siknifikan terhadap keofisien gesek kampas rem, hal ini juga sesuai dengan standar internasional (SAE J661,1997) untuk nilai koefisien gesek kampas rem adalah 0,14 $0,27 \mathrm{~N} / \mathrm{mm}^{2}$, dan pada Tabel 3 diperoleh nilai koefisien gesek terendah pada perlakuan A2 $6 \%$ Alumina) sebesar $0.000765 \mathrm{~N} / \mathrm{mm}^{2}$. Artinya kampas rem ini sudah termasuk dalam kategori standar menurut SAE J661(1997). Berdasarkan standar (SNI 09-0143-1987) nilai koefisien gesek kampas rem sepeda motor adalah 0,30 $0,60 \mathrm{~N} / \mathrm{mm}^{2}$, pada perlakuan A2 (6\% alumina) diperoleh nilai koefisien gesek sebesar 0.000765 $\mathrm{N} / \mathrm{mm}^{2}$, artinya kampas rem sepeda motor ini sudah termasuk dalam kategori standar menurut

Tabel 2. Hasil Uji Kekerasan Rockwell

\begin{tabular}{|c|c|c|c|c|c|c|}
\hline \multirow{2}{*}{$\begin{array}{c}\text { Perlakuan } \\
(\%)\end{array}$} & \multicolumn{4}{|c|}{ Ulangan (Kg) } & \multirow{2}{*}{ Total (kg) } & \multirow{2}{*}{$\begin{array}{c}\text { Rata-rata } \\
\text { (kg) }\end{array}$} \\
\hline & 1 & 2 & 3 & 4 & & \\
\hline A0 (0) & 46 & 62 & 49 & 45 & 202 & 50.5 \\
\hline $\mathrm{A} 1(3)$ & 35 & 40 & 62 & 37 & 174 & 43.5 \\
\hline A2 (6) & 56 & 44 & 60 & 51 & 211 & 52.75 \\
\hline A3 (9) & 36 & 50 & 56 & 43 & 185 & 46.25 \\
\hline
\end{tabular}

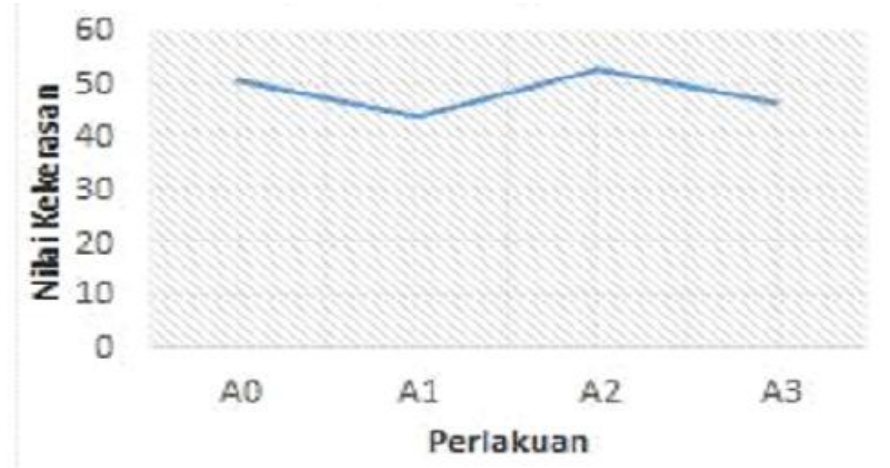

Gambar 1. Grafik Rata-rata Hasil Uji Kekerasan Rockwell 
Tabel 3. Hasil Uji Koefisien Gesek Pin On Disk

\begin{tabular}{|c|c|c|c|c|c|c|}
\hline \multirow{2}{*}{ Perlakuan (\%) } & \multicolumn{4}{|c|}{ Ulangan } & \multirow{2}{*}{ Total } & \multirow{2}{*}{ Rata-rata } \\
\hline & 1 & 2 & 3 & 4 & & \\
\hline A0 (0) & 0.00121 & 0.00103 & 0.00115 & 0.00139 & 0.00478 & 0.001195 \\
\hline & 0.00166 & 0.00115 & 0.00172 & 0.00145 & 0.00 & 0.001495 \\
\hline A2 (6) & 0.00073 & 0.00076 & 0.00088 & 0.00069 & 0.00306 & 0.000765 \\
\hline A3 (9) & 0.00178 & 0.00136 & 0.00169 & 0.00145 & 0.00628 & 0.00157 \\
\hline
\end{tabular}

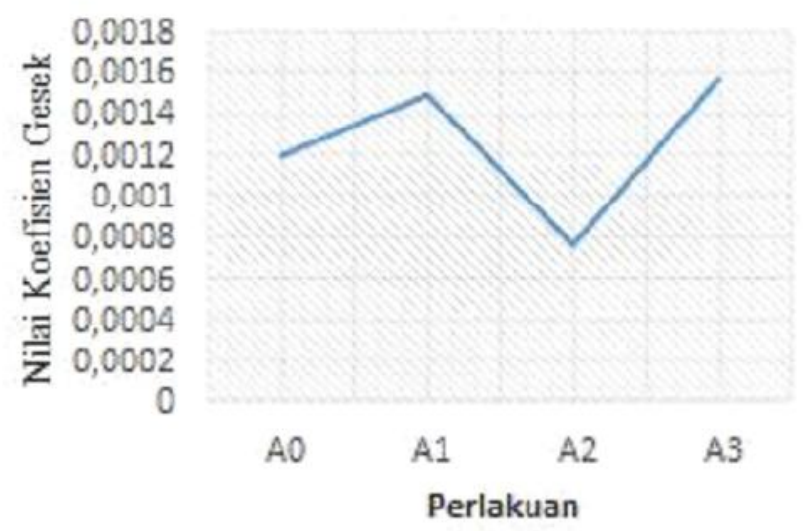

Gambar 2. Grafik Nilai Koefisien Gesek

(SNI 09-0143-1987). Untuk lebih jelas dapat dilihat Gambar 2.

Dari Gambar 2 dapat dilihat bahwa nilai terdapat pada perlakuan A3 ( $9 \%$ alumina) dengan nilai koefisien gesek sebesar $0.00157 \mathrm{~N} / \mathrm{mm}^{2}$ sedangkan nilai koefisien gesek terendah terdapat pada perlakuan A2 (6\% alumina) dengan nilai koefisien gesek sebesar 0.000765 $\mathrm{N} / \mathrm{mm}^{2}$. Pada uji koefisien gesek dengan alat Pin On Disk material yang memperoleh nilai koefisien gesek paling rendah merupakan material yang paling baik.

\section{KESIMPULAN DAN SARAN}

\subsection{Kesimpulan}

Serat pelepah kelapa sawit dapat dimanfaatan sebagai bahan dasar pembuatan biokomposit untuk diaplikasikan menjadi kampas rem sepeda motor. Tingkat kekerasan terbaik kampas rem dari serat pelepah kelapa sawit didapat pada perlakuan A2 (6\% alumina) dengan nilai sebesar $52.75 \mathrm{~kg}$, namun masih di bawah standar kekerasan kampas rem menurut (SAE J661, 1997), yaitu sebesar 68 - $105 \mathrm{~kg}$. Tingkat koefisien gesek terbaik kampas rem dari serat pelepah kelapa sawit didapat pada perlakuan A2
(6\% alumina) dengan nilai sebesar $0.000765 \mathrm{~N} /$ $\mathrm{mm}^{2}$ dan sudah masuk kategori standar menurut (SNI 09-0143-1987), dengan nilai koefisien gesek sebesar 0,25 - 0,60 N/mm² dan (SAE J661, 1997) sebesar $0,14-0,27 \mathrm{~N} / \mathrm{mm}^{2}$.

\subsection{Saran}

Dibutuhkan penelitian lanjutan untuk memperoleh komposisi yang lebih tepat dalam pembuatan kampas rem dari serat pelepah kelapa sawit sehingga dapat memenuhi standard dalam tingkat kekerasan kampas rem. Mengingat keterbatasan alat uji coba, maka peneliti hanya dapat menguji kampas rem dengan uji tingkat kekuatan dan koefisien gesek, untuk selanjutnya diperlukan pengujian lebih lengkap sesuai standar kampas rem menurut SAE J661 (1997).

\section{DAFTAR PUSTAKA}

Aminur, A., Hasbi, M., dan Gunawan, Y. 2015. Proses Pembuatan Biokomposit Polimer Serat Untuk Aplikasi Kampas Rem. Seminar Nasional Sains dan Teknologi, Fakultas Teknik Universitas Muhammadiyah. Jakarta, 17 November 2015. 
Dabuke, M.H. 2018. Pemanfaaatan Pelepah Kelapa Sawit (Elaeis guineensis jacq) Sebagai bahan Baku Pembuatan Tali Serat Alami. [Skripsi]. Universitas Sumatera Utara, Medan.

Direktorat Jenderal Perkebunan, 2019. Statistik Perkebunan Indonesia 2018-2020 Kelapa Sawit. Sekretariat Direktorat Jenderal Perkebunan, Jakarta.

Gibson, R. 1994. Principles of Composite Material. Mc Graw Hill, New York.

Elgani, H.A.R. 2013. Manajemen Penunasan Kelapa Sawit (Elaeis guineensis Jacq) di Sungai Bahar Estate, PT. Windu Nabatindo Abadi, Kalimantan Tengah. Skripsi. Institut Pertanian Bogor. Bogor.
Fitrianto, F.D., Estriyanto, Y., Harjanto, B. 2013. Pemanfaatan Serbuk Tongkol Jagung Sebagai Alternatif Bahan Friksi Kampas Rem Non-Asbestos Sepeda Motor. Nosel, 1(3): 1-11. https://jurnalfkip.uns.ac.id/ index.php/ptm/article/view/1832/1334

SAE J661, 1987. Brake Lining Quality Test Prosedure. Society of Automotive Engineers Internasional

SNI 09-0143. 1987. Kampas Rem Kendaraan Bermotor. Klasifikasi, Dimensi dan Koefisien Gesek. Badan Standarisasi Nasional. Indonesia. 